\title{
Human Rights and the Forgotten Acts of Meaning in the Social Conventions of Conceptual Jurisprudence
}

\author{
William E. Conklin \\ Windsor University \\ wconkli@uwindsor.ca
}

\begin{abstract}
This essay claims that a rupture between two languages permeates human rights discourse in contemporary Anglo-American legal thought. Human rights law is no exception. The one language is written in the sense that a signifying relation inscribed by institutional authors represents concepts. Theories of law have shared such a preoccupation with concepts. Legal rules, doctrines, principles, rights and duties exemplify legal concepts. One is mindful of the dominant tradition of Anglo-American conceptual jurisprudence in this regard. Words have been thought to copy ready-made concepts. Acts of intellectualisation and the accompanying analytic technique have excluded a consideration of a very different sense of legal language. The second sense of a language concentrates upon unwritten acts of meaning which lack a discrete and assignable author. This essay aims to unconceal the importance of an unauthored language. Drawing from Edmund Husserl's early writings, particularly his Logical Investigations, I shall argue that an unwritten language embodies the written language with acts of meaning. An act of meaning confers one's experiential body into the content of a concept signified in a written language. In order to understand the importance of such pre-legal acts of meaning in human rights laws, I begin by outlining how universal human rights have been signified as universal by virtue of their content-independence. I then raise the problem of the exclusion of social-cultural phenomena as elements of human rights laws. The clue to this exclusionary character of human rights law rests in the analytic leap from an unwritten to a written legal language. The essay then addresses the effort to link legality with the social world: namely, the effort of grounding legality in a social convention. I examine how a social convention itself is conceptualized, leaving the remainder of acts of meaning. This failure of social conventions to access social-cultural phenomena encourages me to turn to acts of meaning as such acts were understood by Edmund Husserl in his earlier works. Meaning-constituting acts exist prior to intuitions and prior to social conventions. This priority exists analytically as well as phenomenologically. In order to exemplify this prior character of acts of meaning, I retrieve Antigone's experiential knowledge in Sophocles' Antigone. Antigone's unwritten laws are characterized by an absence of mediating concepts. I then identify several elements of an act of meaning in an unwritten language: the experiential body as the source of the acts of meaning, praeiudicia (prejudgements), collective memories, the act character of meaning, and the act of interpretation of social behaviour. My final section raises the prospect of whether human rights can be considered universal if acts of meaning are that important in the identity of a law.
\end{abstract}

Metodo. International Studies in Phenomenology and Philosophy

Vol. 2, n. 1 (2014)

ISSN 2281-9177 


\section{Introduction}

An untranslatable rupture between two languages permeates the dominant tradition of contemporary Anglo-American legal thought. The tradition has gone by different names: analytical jurisprudence, general jurisprudence, legal philosophy and analytic legal philosophy. More recently, the tradition has been rightly called "Conceptual Jurisprudence" ${ }^{1}$ The one language has been considered the writing authored by such institutions as legislatures, courts and other tribunals. Such historical authors have been said to will or intend a concept or series of concepts. Legal rights, duties, standards, rules, doctrines, and principles exemplify such concepts. Each concept has been believed to possess a core or essence with a penumbra at its fringe. Words have been believed to copy the ready-made concepts. ${ }^{2}$ To this end, lexicography and semantics have been admitted to be important techniques of legal analysis. ${ }^{3}$ Other techniques to access concepts have been elaborated in conceptual jurisprudence. ${ }^{4}$ Concepts have been so important to the written language, according to H.L.A. Hart, that concepts have fused with words into "thought-words". ${ }^{5}$ Legal knowledge has been considered a knowledge about concepts.

Such a knowledge about concepts has excluded from law a second understanding of language. This sense of language is unwritten. The language lacks concepts mediating between an author and social life. Indeed, the language lacks a distinct and assignable author whose acts can be ascertained in quantifiable time and space. This second sense of a language has concentrated upon acts of meaning which constitute intuitions. Human rights law has been no exception to the untranslatable gulf between the two languages.

Drawing from Edmund Husserl's early writings (particularly his Logical Investigations), ${ }^{6}$ I shall argue that an interpreter of writing confers acts of meaning into a written language. But because legal knowledge in a written language has been preoccupied with signified concepts, the legal knowledge has excluded such acts of meaning as pre-legal. I aim to unconceal such excluded acts of meaning in order to better understand human rights. To that end, I begin by explaining that human rights have been considered universal precisely because they have been content-independent concepts. The clue to this content-independence has rested in an analytic leap from a pre-legal unwritten language to the written language of legal knowledge. In an effort to render the concepts socially contingent, the tradition of conceptual jurisprudence has aimed to justify concepts with reference to a social convention. The problem is that what jurists have taken as a social convention itself is a concept. As a consequence, the justification of a concept in terms of a social convention has left a remainder to legality. This exclusion of the unwritten language from identifiable laws suggests that we appreciate how meaning-constituting acts exist analytically and phenomenologically prior to social conventions. I retrieve Antigone's experiential knowledge in Sophocles' Antigone in order to exemplify and describe such a priority. I shall then identify several elements of an act of meaning in an unwritten language: the experiential body as the source of the acts of meaning, praeiudicia (prejudgements), collective memories, the act character of meaning, and the act of interpretation of social behaviour. My

\footnotetext{
${ }^{1}$ Himma 2011.

${ }^{2}$ This point is best elaborated by RAz 2001, 1-37: RAz 1994, 195.

${ }^{3}$ See Raz 2001; "The Problem of the Nature of Law", in Raz 1994; Endicotт 2004, 935-68.

${ }^{4}$ HaRt 2013, v, 13-7, 206-12, 230-44; Finnis 2009, 163-71, reprinted in Finnis 2011, 257-79; Jackson 1998, 23-37; DwORKIN 1986, 65-73, 90-4.

${ }^{5}$ Hart 1954, 37-60 Hart (1954), reprinted in Hart 1983, 21-48, at p. 44. See also Hart 1952, 59-62.

${ }^{6}$ HusserL [1900-1901] 2006, esp. vol. 1, Investigations 1 \& 6.
} 
final section raises the possibility of a universality to human rights despite the socially contingent shared acts of meaning.

\section{Human Rights Laws as Concepts}

The problematic of human rights concerns the considered synonymous relation of a human right with a concept. Indeed, one might best describe human rights law as "conceptual human rights" (as opposed to, say, phenomenological human rights). By conceptual human rights, one human right, as a concept, is distinguished from another human right, as a concept. The scope of a human right is demarcated from another human right by the boundary of the respective concept. A human right is said to be narrow or wide by virtue of the legal space inside the boundary of the concept. More generally, a society is said to respect human rights if human rights concepts have been recognized by institutional authors. Access to human rights is associated with access to the right/concepts and access to the state's legal institutions charged with the obligation of protecting the concepts. A human right concept, the object of ever more intellectually precise and rigorous analysis, becomes the unit of a structure of rights/concepts.

Knowers about human rights, with the tradition of conceptual jurisprudence in the background, have claimed a knowledge about concepts. Words, such as "equal protection", "free expression" or "fundamental freedom", have been believed to copy the concepts. As with human rights discourse, grand theories of rights adjudication have been offered in order to explain the role of concepts. ${ }^{7}$ Ultimate concepts, as the referents of justification, characterize peremptory norms (often called ius cogens). ${ }^{8}$ Human rights concepts have been decomposed into rules and exceptions to the rules. The more refined and rigorous our decomposition of a concept, the more do we jurists assume that we have accessed justice. Various doctrines - "the proportionality doctrine", "the less onerous impact", "the means-oriented test", "the purposive approach" and "onus of proof" - have taken hold of human rights analysis. Concepts have mediated between natural persons on the one hand and the ultimate concept justifying a human right on the other.

To take an example of the mediation of concepts, "freedom of speech" has been guaranteed in texts, both domestic and international. "Freedom of speech" is decomposed into "political speech" and "commercial speech". And "political speech", as a concept, is decomposed into such elements as "expression" as opposed to "action". Once a micro-concept has been ascertained, the jurist has then enquired whether the state has acted within its conceptual boundary. The technique of institutionalizing a restriction of a human right is important. One technique is the enquiry whether a less onerous means interferes with the content of a recognised human right. The point is that the analysis is content-independent. By this, I mean that the content of the concepts lacks the social-cultural assumptions and expectations. To be sure, such ideal-directed norms may be incorporated into the content of a standard/concept. The norms, though, are concepts, themselves content-independent.

To take an example of the content-independence of a human rights standard/concept, Article 16 of the International Covenant on Civil and Political Rights (ICCPR) guarantees that «[e]veryone shall have the right to recognition everywhere as a person before the law». ${ }^{9}$

\footnotetext{
${ }^{7}$ Although all of Ronald Dworkin's works attend to this jurist's obligation, see esp.Dworkin 2013.

${ }^{8}$ Examples are documented in ConKLIN 2012b.

${ }^{9}$ International Covenant on Civil and Political Rights, adopted by General Assembly Resolution 2200A (XXI), 16 December 1966, entry into force 23 March 1976, 999 UNTS 171 [ICCPR].
} 
How is it possible that everyone on the globe is a "person" before the law? Such a universality would only be possible in a structure of concepts if "a person" were not a natural person with such elements as a biography, personal and collective memories, social relationships, a social role and expectations. The only way that persons can be universally recognized is that they are represented as legal concepts independent of their personal and collectively shared, social-cultural identity.

Immanuel Kant had this content-independence in mind when he described dignity as an a priori concept independent of social-cultural phenomena. The referent, "dignity" highlighted in human rights texts, reminds one of Kant's a priori concepts. ${ }^{10}$ Kant explained that universal dignity was a concept lacking any measurable value:

Whatever has reference to general human inclinations and needs has a market price; whatever, without presupposing any need, accords with a certain taste, i.e, a delight in the mere unpursiveness play of our mental powers, has an affective price; but that which constitutes the condition under which alone something can be an end in itself has not merely a relative worth, i.e., a price, but has intrinsic worth, i.e., dignity.

In order to have an equal and inalienable human right, there has to be some content-independent, higher-ordered concept, such as "dignity", which justifies the equal and inalienable nature of other rights. Universal human rights have been assumed to exist as if intellectually transcendent of the unwritten language of socially contingent experiences. In the context of Article 16 of the ICCPR, 12 million natural persons on the globe lack recognition as a legal person. ${ }^{11}$ And tens of millions of inhabitants of the globe possess recognition as legal persons but effectively lack such recognition in socially contingent circumstances. ${ }^{12}$ Both equality and personhood are a priori concepts, leaving the biography of an experiential subject immaterial.

Let us address the human right of non-discrimination. Article 2 of the ICCPR provides that «[e]ach State Party to the present Covenant undertakes to respect and to ensure to all individuals within its territory and subject to its jurisdiction the rights recognized in the present Covenant, without distinction of any kind, such as race, colour, sex, language, religion, political or other opinion, national or social origin, property, birth or other status.» ${ }^{13}$ Once again, a right, such as non-discrimination on the basis of "national origin" or "religion", is a concept about discrimination and a concept about national origin or religion. An intellectually constructed boundary separates one concept, say colour, from another concept, say religion.

The problem is that the differentiation of one human right as a universal concept from another universal concept excludes the "pre-legal" singularity of an experienced event. To be sure, the concept is later applied to natural persons who had experienced the event. Such an application of the concept analytically occurs after the human right is inscribed as a represented concept. The boundary of the concepts is clarified and

\footnotetext{
${ }^{10}$ Kant [1797] 1996, 435-6.

${ }^{11}$ The figures for 2012 and 2011 indicate such a figure. UNHCR, Global Trends 2011: a Year of Crises (UNHCR, Geneva: 18 June 2012) available at: http://www.refworld.org/docid/4fdeccbe2.html; UNHCR, Global Trends 2012, "Displacement: the New 21 ${ }^{\text {st }}$ Century Challenge" (UNHCR, Geneva, June 2013), http : //unhcr . org/globaltrends june2013.pdf. However, one summary indicates 10 million. UNHCR, Statistical Yearbook 2012, "Stateless Persons Statistics" ("Stateless People Figures"), UNHCR 2001-2013 http: //www . unhcr. $\mathrm{org} / \mathrm{pages} / 49 \mathrm{c} 3646 \mathrm{c} 26$. html; UNHCR, Year of Crises above n 1, 2 UNHCR, Global Trends 2012 (UNHCR, Geneva, June 2013), "Annexes (Excel Tables)", 2. Available at: http://unhcr.org/globaltrendsjune2013/ UNHCR\%20GLOBAL\%2OTRENDS\%202012_VQ5.pdf.

${ }^{12}$ ConKLin 2014, 96-135.

${ }^{13}$ International Covenant on Civil and Political Rights, adopted by General Assembly Resolution 2200A (XXI), 16 December 1966, entry into force 23 March 1976, 999 UNTS 171, Art. 2.
}

Metodo. International Studies in Phenomenology and Philosophy

Vol. 2, n. 1 (2014) 
then applied to the experienced event. The contingent social-cultural phenomena are enclosed inside the boundary of the right as a concept. The right/concept post facto reduces the particular context-specific experience into a conception. The analytic relation between concept and singular experienced event becomes reversed despite the fact that the context-specific event exists before the law/right. Without the experienced event before the identity of a human right/concept, the right/concept remains in a heaven of a priori concepts.

To be sure, a concept such as "equal persons", "freedom of speech", "dignity", "non-discrimination" or "equality before the law" may be circulated in different textual contexts. What we jurists have assumed, largely through the success of a professional legal education, is that concepts constitute the reality of human rights. We even describe the clarification and application of concepts to an experienced event as "practice". And so, an examination of the social-cultural presuppositions of the content of a human right is considered extra-legal. Legal progress is marked if concepts are increasingly clarified and differentiated with ever-more rigorous decomposition of concepts. Legal history itself is studied as if a history of concepts. ${ }^{14}$ Even the history of a micro-concept, such as political speech or commercial speech, risks being retrieved as a history of a concept in the sub-text. By identifying the "evolution" of a concept, we come to believe, conceptual human rights represents social practice. The boundary of any such ultimate referent of justification is ever-wider in scope, the higher in the order of concepts is our justification of the right. In addition, the concept's universality hinges upon its independence of social-cultural specificity. In sum, human rights and their justified referents are content-independent a priori concepts. The concepts relate to each other in an autonomous metaphysical system or structure. ${ }^{15}$ Concepts now define what counts as a human rights law and what is extra-law.

\section{The Problem}

The tradition of conceptual jurisprudence takes for granted that a human right, as a legal concept, must be justified. The justification is directed towards a referent. The referent has varied. One referent has been the institutional source of the state. Known as the sources thesis and best represented by the works of Joseph Raz, a human right would be legally recognized if it could be justified in terms of a statute or precedent or a still higher source such as a quasi-constitutional or constitutional text. A second justificatory approach has appealed to a higher-ordered concept, such as dignity, or a higher-ordered theory of the constitution. The ultimate concepts have been said to be such a priori concepts as respect for persons (Immanuel Kant) ${ }_{1}^{16}$ the greatest good (J.S. Mill) ${ }^{17}$ equal consideration (Bernard Williams), ${ }^{18}$ equal respect and concern (Ronald Dworkin) ${ }^{19}$ secondary recognition respect as opposed to appraisal respect (Gregory Vlastos and Stephen Darwell), ${ }^{20}$ the species (Karl Marx), ${ }^{21}$ and "humanity". ${ }^{22}$ Ronald

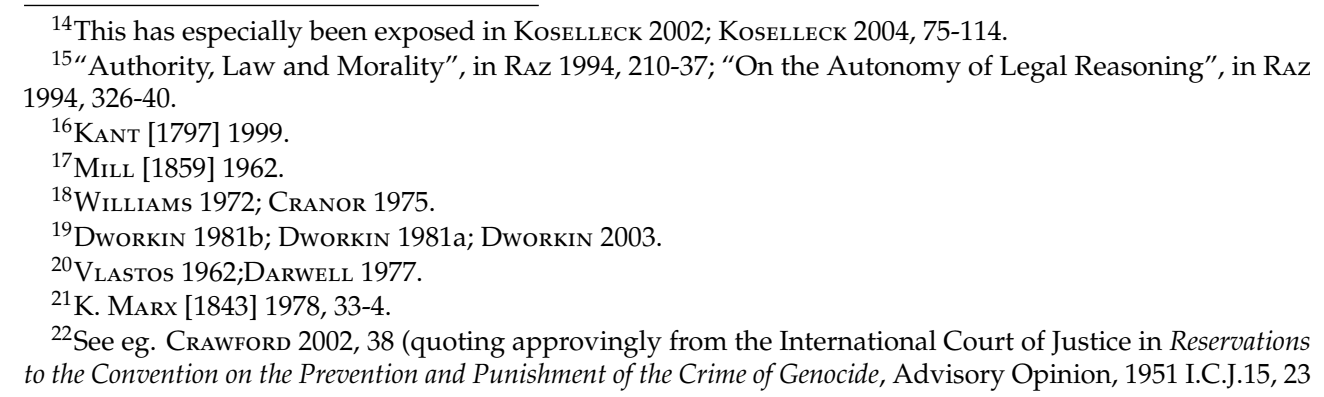


Dworkin's theory of human rights best exemplifies this second approach, an approach which I am leaving for another effort. The third approach justifies a human right in terms of a social convention. This approach has been highlighted in customary international norms. Some constitutional discourses, such as the Canadian, have recognized conventions as binding. Here, the tradition of conceptual jurisprudence has associated a social convention with a regularity of social behaviour. Although I shall take up this third approach in order to exemplify the problem of conceptual jurisprudence in the context of human rights law, each approach shares a common problem: namely, the association of the identity of a law with a concept. ${ }^{23}$

\subsection{The Exclusionary Character of a Clarified Conceptual Boundary}

The crucial juristic role in conceptual jurisprudence aspires to clarify how a human right can be identified as a social convention. Hart has expressed the objective of conceptual jurisprudence more generally: the central objective of legal theory, he wrote in his posthumous "Postscript" to the Concept of Law, is the «explanatory and clarifying account of law as a complex social and political institution with a rule-governed (and in that sense 'normative') aspect.» ${ }^{24}$ This objective proceeds without the jurist needing to address the pre-legal conditions constituting the habits and other intuited objects making for a habit or ritual. The «rule-governed aspect» - what I have emphasized in section one as "human rights as concept-centered" - incorporates concepts said to represent «a complex social and political institution». After all, Hart entitled his influential book, The Concept of Law. The justified concepts are considered reasons for action for subsequent official decisions or behaviour. ${ }^{25}$ The consequence is that human rights are situated in a structure of inter-related concepts. An unwritten language, as unauthored, is excluded from such a knowledge about concepts.

\subsection{The Reification of the Concepts}

The problem is that the more analytically rigorous one's clarification of the boundary of a right/concept and therefore of the identity of a human right, the more distant and reified is the human right vis-à-vis socially experienced events. Put differently, the more we succeed in accessing the core of a right as a concept, the more is the right purified from context-specific content of the right/concept. The boundary of one concept/right is differentiated from the boundary of another. We intellectually construct human rights as concepts and then apply the concepts to social circumstances. The ironic point is that when we take human rights as an "is" of reality, it is really an idealised heaven of content-independent a priori concepts.

In this way, human rights and ultimate referents become reified vis-à-vis the unwritten language. Human rights, as concepts, also exist from the standpoint of the present. That is, we observe and apply the right/concept backward from an external standpoint. What matters is a conceptual law and a conceptual history, not something whose contents are drawn from context-specific acts of meaning in

(May 28). See also Dubois (2009), pp. 154 n. 72, 155 n. 77; Schlütter (2010), pp. 74-79; Attorney General of Israel v. Adolf Eichmann, District Court of Jerusalem, 36 Int'l Law Rep 18, 25, 26, 50 (Israel Dist. Ct. 1961); 36 Int'1 Law Rep 277, 299, 304 (Israel Sup. Ct. 1962).

${ }^{23}$ Hart 2013, 13-7. See also Kramer 2000; Kramer 2002; Kramer 2004; Dickson 2004; Leiter 2003; Raz 2001; “The Problem of the Nature of Law" in Raz 1994; ENDicotT 2004.

${ }^{24}$ HART 2013, 238.

${ }^{25}$ This is best elaborated in RAz 1978; WIgGINs 1978.

Metodo. International Studies in Phenomenology and Philosophy

Vol. 2, n. 1 (2014) 
experiential time and space. ${ }^{26}$ For one thing, because social progress is assumed to be measurable in terms of the intellectual decomposition of the boundaries of concepts into micro-elements of the boundary, the social content of the concept/right may change as time is experienced.

\subsection{The Inaccessible Analytically Prior Experienced Events}

There is a more serious problem, though, is that in the quest for the identity of a human rights concept, a singular context-specific experienced event is inaccessible to the written language of concepts. Instead, the experienced event is reduced by the signification of a general rule/concept. This inability to recover or represent a singular experienced event has been reinforced by the conceptual character of an identifiable law.

So, let us return to the ultimate justified referent of dignity in human rights law. The privileged role of "dignity" blocks off the social-cultural phenomena until we intuitively respond to the phenomena, not to the concept of dignity. That is, the concept of dignity is not applied to a singular social-cultural event until after a natural person has already experienced the event. Without a recognition and study of the social-cultural condition generating the event, human rights laws abstract the socialcultural content of the concept as if the reified abstractions constitute social practice. At one point, for example, European international law discourse represented "dignity" as possessed by the king. At another point, the state was described as possessing "dignity". Of course, by post-World War Europe, treaties and judicial judgments claimed a "dignity" owed to all legal persons independent of the state. More recently, legislation has been described as having a "dignity". ${ }^{27}$ The content of each sense of dignity has been understood in an historical a priori. This historical a priori, nested in the unwritten language, is an existence condition of a structure of concepts before "dignity" can be even conceptualised. Pre-legality, as a remainder to concepts, is radically contingent. Because the social-cultural content of such an a priori concept has been excluded from the knowledge of dignity as a concept, one can speak of a succession of the concepts of dignity as if each concept were a-historical.

In like vein, international law discourse has highlighted the "existence" of an "international community" for some centuries. The problem is that the concept of an "international community" too has had a different social-cultural content in different historical a priori. One international community was said to exist by virtue of Christendom, another by virtue of customs shared in the domestic laws of states, still another by a basic text, such as the United Nations Charter and still another by international customary norms. ${ }^{28}$ One sense of an international community has been considered the aggregate of the wills of state members. ${ }^{29}$ Another sense has held out an «international community as a whole» independent of the wills of state members. ${ }^{30}$ Even what jurists have taken as the concept of a legal bond of the natural person to the state has varied from the voluntary choices of a natural person in $17^{\text {th }}$ century legal treatises to the allegiance of the person to the state in $19^{\text {th }}$ century treatises. By the 1920s and '30s, legal commentaries deferred to the state's freedom to posit whether a

\footnotetext{
${ }^{26}$ How experiential legal time and space differs from chronological time and territorial space is outlined and examined in Conklin 2006a; Conklin 2007.

${ }^{27}$ WALDRON 1999.

${ }^{28}$ See ConKLIN 2012c; Conklin 2012b.

${ }^{29}$ This sense is elaborated and documented in CoNKLIN 2014, 96-135.

${ }^{30}$ See, CoNKLin 2014, 30-64, 271-301.
} 
national was loyal to the state. ${ }^{31}$ Even the word "freedom" has had a social-cultural content that has varied in a different historical a priori. Although the state was initially considered free in $17^{\text {th }}$ century European treaties, the natural person was considered free in late $19^{\text {th }}$ century political and legal commentaries. Jurists now write about «the architecture» of the autonomous «structure» of human rights independent of a state's freedom. ${ }^{32}$ Despite the variable and historically contingent content of such critical concepts as "the international community", "the legal bond" and "freedom", human rights, as bounded concepts, are fixed in calendar time and territorial space. Human rights are considered universally shared if justified by higher-ordered concepts as if analytically prior to the singularity of an experienced event. The more often courts and tribunals cite and quote the signs representing the concepts in any particular society, the greater the temptation to believe that human rights exist.

\section{The Analytic Leap from an Unwritten to a Written Language}

What transpires in the human rights legal discourse, against a background of conceptual jurisprudence, then, is an analytic leap. As a consequence of the leap, the social-cultural content of human rights concepts is excluded from the elements of an identifiable law. The leap ventures from the unwritten language of singular, experienced events on the one hand to concepts on the other. The former is nested in an unwritten language and the latter in a written language. In order to maintain a structure or system of content-independent concepts, an untranslatable gulf has had to be maintained. As Hart stated,

No doubt as a matter of history this step from the pre-legal to the legal may be accomplished in indistinguishable stages, of which the first is the mere reduction to writing of hitherto unwritten rules. This is not itself the crucial step, though it is a very important one: what is crucial is the acknowledgement of reference to the writing or inscription as authoritative, i.e. as the proper way of disposing of doubts as to the existence of the rule. ${ }^{33}$

The written language has required "the crucial step" because laws and theories about laws have identified laws as concepts. ${ }^{34}$ The analytic "crucial step" continues into the present. It can also be discursively traced to Immanuel Kant and indeed, to early modern theorists. ${ }^{35}$ Hegel described the disjunction, for example, as a necessary "leap". ${ }^{36}$ The leap has even been considered necessary for jurists to understand the nature of binding laws in stateless societies. ${ }^{37}$ Statutes and precedents have represented (that is, signified) the a priori concepts intellectually transcending a context-specific event. This has been so because a code is assumed to be authored (by a legislature or court) and a concept is believed to be willed by the institutional author who consciously reflects and deliberates about the content of the concept. This act of intellectualisation depoliticizes and neutralizes the singular experienced event by transforming it into a general concept. The experienced event can now be "known". It can be known by the jurists as a concept without our ever having to return to a study of the concrete experienced event as an element of an identifiable law.

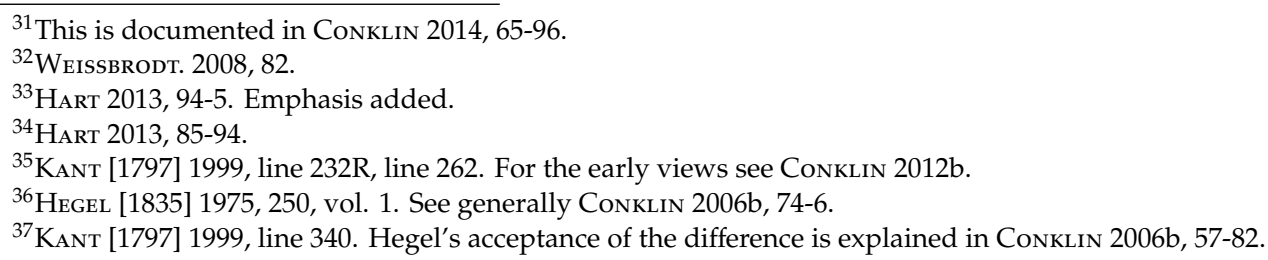

Metodo. International Studies in Phenomenology and Philosophy

Vol. 2, n. 1 (2014) 
Although we could turn to Thomas Hobbes, Hugo Grotius or even Plato to seek out the details of various examples of an analytic legal philosopher, ${ }^{38}$ the foremost scholar of the legal analytic method was Jeremy Bentham. Bentham described his method as a «method new in itself», «original» and what «most assuredly has never been taken hitherto». ${ }^{39}$ Bentham aimed to bring coherency and rationality to a legal structure that was plagued with incoherent customs. ${ }^{40}$ The thrust of his method was to take a concept, such as "possession", divide the concept into its parts, and then aggregate the parts into an inter-related structure or system. Bentham identified several features of the self-described "original" analytical method: paraphrasis, phraseoplerosis and the sign. ${ }^{41}$ Bentham's analytic technique has remained with contemporary Anglo-American conceptual jurisprudence. ${ }^{42}$ Matthew Kramer, for example, has identified meta-ethical features in the analytic technique in a manner which replicates Renaissance science. ${ }^{43}$ Julie Dickson has restated the analytic technique in terms of Renaissance science: simplicity, clarity, elegance, consistency and comprehensiveness. ${ }^{44}$ Brian Leiter has added evidentiary adequacy, minimum mutilation of well-established frameworks and methods, and explanatory consilience. ${ }^{45}$ The important point is that the analytic technique has presupposed that the role of the jurist and of the legal philosopher has been to clarify the boundary of a concept.

Independent of the analytic technique, the objective of a statute or treaty is also framed as a concept. A concept is believed to be self-consciously willed or intended by the legislative or judicial author. Once inscribed, the will is justified with reference to an aggregate of ready-made concepts. When it comes to international law concepts, the content-independence of the concepts leaves the enforceability of the concepts with the state. ${ }^{46}$ It makes sense, given the analytic priority of concepts over singular experienced events, that conceptual human rights can hold out one society as more human rights-oriented than another. So too, the human rights, as concepts, become highly reified from the social life of human beings. The experienced events are represented in legal analysis after the clarification of human rights concepts. Legal knowledge, as a knowledge of concepts, excludes the experiential event as an element of legality.

Not surprisingly perhaps, jurists have offered little insight as to the nature of the excluded pre-legality. That said, Hart does recognise the pre-legal experiential events when he asserts that «[t]he figure of a bond binding the person obligated [.] is buried in the word 'obligation', and a similar notion of 'debt' latent in the word 'duty' [...] .» ${ }^{47}$ This figure of a bond «haunts much legal thought», he urges, as if it were «a chain binding those who have obligations so that they are not free to do what they want [my emphasis].» Hart acknowledged that pre-theoretical differences

\footnotetext{
${ }^{38}$ One can sense the influence of Hart's own professor, H.W.B. Joseph, upon Hart. Joseph's lectures on the Theaetetus had concentrated upon Plato's analytic method. See JosEPH 1948. Joseph's lectures were delivered in 1925.

${ }^{39}$ Bentham [1782] 1970, App. C, para. 17; Bentham [1789] 1970, 196, ch. 16, fn. q.

${ }^{40}$ ВеNтHAм [1789] 1970, 196.

${ }^{41}$ See Bentham [1789] 1970, App. B, para. 1; App. C, fn c. Hart discusses the method in Hart 1982, 130-1.

${ }^{42}$ See eg., RAz 1994.

${ }^{43}$ Matthew Kramer identifies the cardinal analytic values as consistency and regularity (or uniformity). KrAMER 2000, 99. He adds such values as comprehensiveness, explanatory power, subtlety, non-redundancy, precision, plausibility and clarity: KRAMER 2004, 326. On another occasion, he adds co-ordination: KRAMER 2002, 142

${ }^{44}$ Dickson 2004, 125, 135.

${ }^{45}$ Leiter 2003, 34.

${ }^{46}$ FitzPATRICK 2005, 9-13; FitZPATRICK 2003.

${ }^{47}$ Hart 2013, 87.
} 
might well have explained why Hart and Fuller saw the world so differently: «I am haunted by the fear that our starting-points and interests in jurisprudence are so different that the author and I are fated never to understand each other's work.» ${ }^{48}$ A consideration of pre-legality as an element of identifiable laws, Hart once wrote, would cause a «nightmare». ${ }^{49}$ Despite extraordinarily personalised attacks by jurists of their contemporaries, antagonists have shared a common assumption: that theories of law involve concepts. Non-concepts are excluded as extra-legal. ${ }^{50} \mathrm{My}$ effort, then, aims to retrieve one effort to link concepts to the non-cognitive phenomena.

\section{5 "Social Conventions"}

The tradition of conceptual jurisprudence has offered various ultimate referents in the justification of a legal concept. Again, the one has justified a concept in terms of an institutional source of the state. Another has begun with intuitions, convictions and values and, from there, to elaborate conceptions and a coherent general theory of a constitution. ${ }^{51} \mathrm{~A}$ third has highlighted how any concepts can be justified with reference to a social convention. I shall take up the latter approach in order to argue how the concepts have been content-independent of the socially contingent experienced events.

a) A Social Convention as a Regularity of Social Behaviour. Jurists have often taken the constitution of "social conventions" for granted. ${ }^{52}$ In his earlier writings, Hart considered that a "social convention" is a convention concerning the ordinary use of words. ${ }^{53}$ With such a social convention as the use of words, there would be no universal a priori concepts. An official could not argue that a particular use of words was illegal, only that one use was inconsistent with the social convention as the ordinary use of a particular word.

With such a problem in mind, it is not surprising that although Hart continually referred to the ordinary use of words in his Concept of Law, he shifted his emphasis to the regularity of social behaviour as the justificatory foundation of the concept of law. ${ }^{54}$ More recent commentators have taken a social convention as synonymous with such a regularity of social behaviour. ${ }^{55}$ The regularity is a concept. A "social convention", such as a doctrine of precedent or the doctrine of legislative supremacy, is accepted as fixed beyond the jurist and independent of the structure of concepts. The conventions are often described as "social facts" or "data". ${ }^{56}$ The conventions are observed as if measurable objects separate and pre-existing the observer official. The data are so important to the possibility of the structure of concepts that jurists are urged to become social scientists. ${ }^{57}$ Whether social scientists or the closed elite that Hart had in mind, a theory of law justified in terms of social convention rests with

\footnotetext{
${ }^{48}$ HART $1983,343$.

${ }^{49}$ HART 1977.

${ }^{50}$ Until recently, an excellent example of the tenor and substance of the adversarial nature of the enemies in conceptual jurisprudence is in DWORKIN 2002 and LeITER 2003. For a more recent and extraordinary example, see the chain of claims and counter-claims "ending" with Kramer 2011; Simmonds 2011.

${ }^{51}$ See esp.Dworkin 1977, 48-50, 54-5; Dworkin 1986, 87-94; and Dworkin 2013, 136, 157-88, 403-5.

52 As an example, See Leiter 2011. The closest that Leiter comes to elaborating "social facts" is to say that they are «facts about how officials actually decide disputes» (LEITER 2007, 126). The social experiences of the non-experts once again remain a part of the excluded pre-legality.

${ }^{53}$ HaRT 2013; HaRT 1954.

${ }^{54}$ Hart 2013, 56, 89-90.

${ }^{55}$ See eg. Coleman 2003, 74-102; MacCormick 2008, 43-5.

${ }^{56}$ MACCORMick 2008, 111.

${ }^{57}$ Leiter 2001; LeIter 2007, 153-99.
}

Metodo. International Studies in Phenomenology and Philosophy

Vol. 2, n. 1 (2014) 
expert knowers of rights/concepts. ${ }^{58}$ Because Hart advocated the juristic observation of data, Hart described his concept of law as a «descriptive sociology». ${ }^{59}$

b) The Regularity as a Concept. A regularity of social behaviour is a concept. A regularity, though, abstracts from a multiplicity of singularly experienced events. As a consequence, experienced events dissolve into concepts (rights) about a concept (a regularity) without the jurist ever having to address the conditions generating the regularity of social behaviour. The same may be said of an association of a social convention with the ordinary use of a word. Stephen Perry, for one, has recognized this problem. ${ }^{60}$ Without addressing the element generating a social convention, a convention is posited. Perry calls this form of legal analysis, «methodological positivism». ${ }^{61}$ The way-out of the positivism, according to Perry, is to examine the conditions making for a social convention. Such conditions, though, concern the jurist's justification of the social convention. The justification concerns, in turn, the justification of "our" acceptance of a social practice. ${ }^{62}$ Such is said to constitute an "internalist" standpoint. As Perry says, the jurist must «make sense of law to $u s$ - that is those who engage in or are subject to law - by offering an account of whether and how the law's claim to authority over us might be justified.» ${ }^{63}$ But the justification must "give us reasons for action». ${ }^{64}$ The reasons, needless to say, are concepts. When one considers a social convention as the factual basis of the foundation of the structure of laws, the concepts become a-temporal. The conditions generating the social conventions are thereby immune from historically contingent phenomena.

c) The Convention as Critical Thinking about a Habit or Ritual. The conceptual character of a convention differs from a habit or ritual. A habit lacks any self-reflection by a member of a group as to whether the habit is a regularity or rule. ${ }^{65}$ A group member feels immediate with the habit. Obedience to a legislator's habit, according to Hart, does not justify the legislator's successor to have authority to enact a law nor does a habit justify one's obligation to obey the habit. ${ }^{66}$ What does render a habit obligatory, in Hart's view, is the critical reflection which transforms the habit into an obligatory. ${ }^{67}$ The official gains a sense of obligation to follow or be guided by the habit. Such self-reflection about a habit renders the habit rule-like or, better, concept-like. ${ }^{68}$ Interestingly, the critical reflection is not that of the populace but of officials. ${ }^{69}$ Critical reflection transforms a mere habit into a rule and a rule is a mere concept. Thus, the foundation of the legal system is a concept which jurists self-consciously recognize as if a rule/concept. ${ }^{70}$ Such critical reflection is «the normal, though unstated, background or proper context for binding concepts.» ${ }^{71}$ As such, the "conventionality thesis" is thought to assure one of the legal validity of a concept.

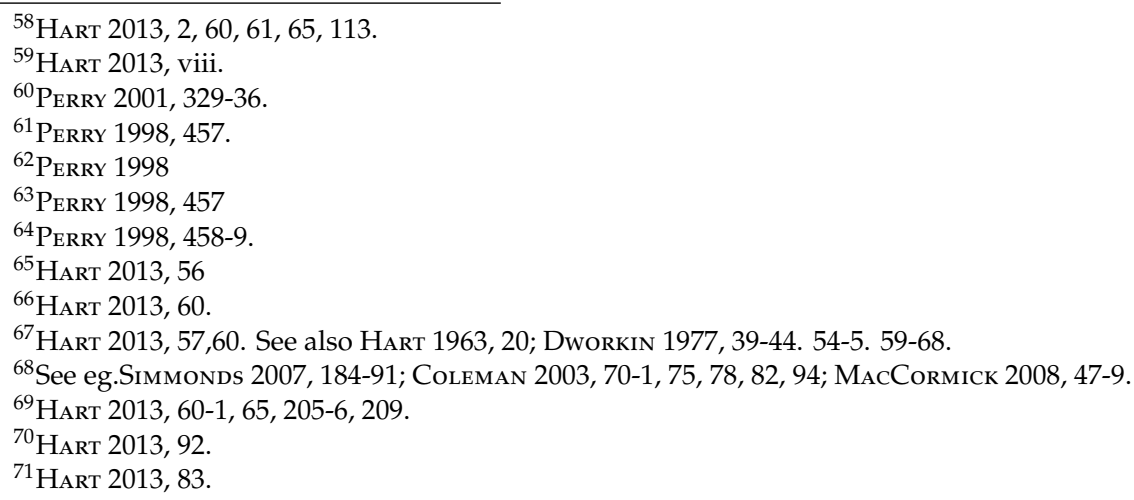




\subsection{The Exclusion of Social Phenomena as Elements of Social Conventions}

Accordingly, attitudes, feelings and beliefs are excluded from the concept of law because they are «unofficial rules [that is, unofficial concepts]». ${ }^{72}$ «Unofficial rules» [sic concepts] characterize «rudimentary» social and political organizations. A traditional society is imagined as possessing such «rudimentary» social and political organisations. In contrast, a regularity of social behaviour is about primary rules/concepts in a state. A regularity is even described by one jurists as «practice». ${ }^{73}$ In this way, what is taken as "practice" is really a concept which abstracts from a multiplicity of experienced events. As a consequence, particular acts of meaning generating the shared features of a convention are forgotten in the system of law.

Once again, a "social convention" becomes a concept. What is taken as a "social convention" is a general rule or concept about habits which in turn express singular experienced events. Social conventions are observed as "facts" by acts of intellectualization. Critical reflection is just such an act of intellectualisation because the conventions become generalized concepts. The concepts are "observed" as things. A "social convention", as noted above, is reduced to a general rule/concept. The jurist is left with the claim that $\mathrm{s} / \mathrm{he}$ interprets concepts rather than signs representing concepts. ${ }^{74}$ We can recognize the regularity of social behaviour because the regularity is a concept independent of the heterology of acts of meaning constituting intuited objects. One may "know" a "social convention" as a general regularity, which itself is a concept or rule, about social behaviour. A right/concept recognizes a concept in a conceived legal objectivity. The representation mediates between the concept of an experience and the concept as a reason for action. The network of concepts is said to represent an objectivity.

With the «internal standpoint» of conceptual jurisprudence, the official is guided by concepts in her/his evaluation of her/his own and others' behaviour. ${ }^{75}$ The concepts function as reasons for legal action. Accordingly, what is taken as a "fact" or "experienced event" is conceptualised. The concept is super-added onto the concept (regularity) without having to consider, let alone evaluate, a singular experience from which one confers an intuitive object.

After all, "social conventions" are said to function as the starting point for the foundation of the legal order. The foundation of the structure of concepts is said to be a rule (sic, a concept) of recognition. This concept, in turn, is said to recognize a "regularity". A "regularity" itself, though, is also a concept. A regularity generalises about a multiplicity of discrete experienced events. This exclusionary character of law continues in the distinction of "social facts [sic. concepts]" vis-à-vis "primary rules/concepts". A secondary rule is parasitic, we are advised, upon primary rules/concepts. Once again, the particular experienced event is not accessed or even represented through the analysis of human rights concepts. The most basic concept of a legal structure, the rule of recognition, has become a concept [the rule] recognising a concept [regularity] about primary rules [concepts].

As such, social conventions fail to address the constituting conditions of the intuitions generating habits. The concept of the regularity becomes the ultimate referent for the justification of a valid legal rule/concept. The rule of recognition itself is said to recognise a general concept about social behaviour. This concept abstracts

\footnotetext{
${ }^{72}$ HART 2013, 92.

${ }^{73}$ See Coleman 2003, 152.

${ }^{74}$ Ronald Dworkin best exemplifies such a prospect. See Dworkin 2013.

${ }^{75}$ HarT 2013, 88-91, 98-9.
} 
from social experience. This is especially so in that the object of the "regularity" is not a social experience nor even a regularity of social experiences but primary rules/concepts.

In addition, the validity of any rule (sic, a concept) depends upon a justificatory act. The concept has to be justified in terms of the ultimate referent, the concept of recognition. The concept of recognition, though the origin of the system of concepts, becomes the fixed justificatory source of subsequent rules. Once again, then, social practice is excluded from legal knowledge. The whole project of legality is lifted from what is unwritten language into acts of intellectualisation directed towards a metaphysical world.

\subsection{The Priority of Concepts over Words in a Written Language}

It would be an error, then, to assume that the written language hinges upon the writing inscribed by an institutional author. This is so for two reasons. First, the starting point of language, for the tradition of conceptual jurisprudence, is a concept. The concept is assumed to be ready-made, separate from the justifying source of the concept and separate from the jurist's intellectual clarification of the concept. A word or phrase merely names a concept. In this content, the name copies the concept as if the concept were ready-made and the word transparent. Accordingly, what is taken as a language - that is, the words denoting a ready-made concept - is directed towards the core or essence of a concept with a penumbra at its boundary. ${ }^{76}$

Second, for conceptual jurisprudence, language is the product of an analytic technique in clarifying the boundary of a concept. Although narratology and interpretation have been highlighted in conceptual jurisprudence, the interpretation has been of concepts, not of the words representing the concepts. ${ }^{77}$ Being ready-made, the concept is believed to exist prior to the author ever intending the concept and before any posit of a word to copy the concept. In sum, for conceptual jurisprudence, we learn the words as if we also learn the pre-existing concepts.

The challenge for the philosopher of conceptual human rights, then, is to ensure that a correct sign is chosen to represent the freedom as a ready-made concept. Clarity of the boundary of the concept becomes the primary objective for human rights law. The words may signify freedom of speech or some other human right. But the concepts, copied as words, are decomposed in order to access the identity of a human right. The experiential knowledge constituting the remainder of pre-legality is long forgotten. Worse, the jurist forgets that the experiential knowledge was forgotten. This is most ironic in that Hart himself described his own effort of focussing on concepts as «throw[ing] light which makes us see much in law that lay hidden; but the light is so bright that it blinds us to the remainder and so leaves us still without a clear view of the whole. ${ }^{78}$ The remainder which Hart had in mind was a system of rules/concepts. Such a preoccupation with a system of concepts, in turn, did have a remainder. But the remainder, said to be "pre-legality", was a product of the analysis of concepts. The pre-legal experienced event also remained forgotten in such a conceptualised pre-legality.

The question arises as to whether the concepts are accessible by words and

\footnotetext{
${ }^{76}$ HART 1958.

77 The best example is Dworkin 1977, 48-50, 54-5; Dworkin 1986, 87-94; and Dworkin 2013, 136, 157-88, 403-5.

${ }^{78}$ HART 2013, 2.
} 
sentences. ${ }^{79}$ Intermediate words and phrases are familiar in human rights law: proportionality, the "is-ought" doctrine, the causality doctrine, the doctrine of rational coherence, and the like. The philosopher can identify the words and their external relation with concepts. But the words/sentences resemble artefacts in a museum. For, the words and the represented concepts are detached from social life, the social life of expert knowers as well as of non-expert knowers of the "thought-words". Indifferent to the social conditions generating social conventions, the words and represented concepts are arbitrarily posited. The social conditions are concealed. The philosopher "observes" and "records" social practices in order to recognize a concept which becomes the final referent for the validity of subsequent concepts without inquiring about the unwritten language. Contemporary conceptual human rights move back and forth between the social conventions as the existence conditions of the legal order on the one hand and to the concepts as reasons for action on the other. Conceptual human rights become indifferent to the social conditions excluded from legal knowledge as pre-legal. Merleau-Ponty described the shift from the abstraction of social conventions to concepts as «a bastard process [...] which denies scientists the final interpretation of the very facts that they have taken the pains to assemble, and which compromises philosophy with the always provisional results of scientific research.» ${ }^{80}$ Such an optical illusion has characterized the effort to link the structure of legal concepts to the social world by justifying the concepts with reference to social conventions.

\section{The Acts of Meaning of an Unwritten Language}

Let us now turn to an element of the unwritten language in an effort to retrieve just such a social world. So far, I have suggested that pre-legality draws from the singularity of an experienced event. I now aim to flesh out a particular feature of such a singularity. By a singularity I do not mean an event which begins ab initio from the individual natural person. The event is a social, not a solipsistic, event because of the constituents of acts of meaning: the personal and collective memories, teachers, parents, social groups and context-specific social relationships generally. Such factors induce an act of meaning as elaborated by Edmund Husserl in his early writings. ${ }^{81}$

\subsection{The Meaning-Constituting Acts of an Intuition}

An act of meaning constitutes an intuition. The act embodies the intuition analytically before an author reflects and deliberates about the content of a concept in a written language. The act of meaning is unwritten in that it lacks a discrete and assignable author or, for that matter, origin. A legislature or court exemplifies such an author. The members of such institutions self-consciously reflect and deliberate about the content of concepts signified by texts such as statutes, judicial reasons, treaties and the like. In this vein, a conceptual human right is identified by its authorial source, the source being an institution of the state, a higher-ordered concept/theory or a social convention.

The clue to the assimilation of an act of meaning in an identifiable law is that a human right is consciously authored. The act of meaning lacks a discrete time and place of its being authored. More importantly, an act of meaning is not self-consciously authored. The act of meaning is pre-intellectual. It lacks a discrete and assignable

\footnotetext{
${ }^{79}$ The question is posed in DerRIDa [1994] 2002, 230-58.

${ }^{80}$ Merleau-Ponty [1960] 1964, 99.

${ }^{81}$ Husserl [1900-1901] 2006. See also Schutz [1953-1954] 1967, 13-4, 61-2, pp. 13-14, 61-62.
}

Metodo. International Studies in Phenomenology and Philosophy

Vol. 2, n. 1 (2014) 
author. The act of meaning exists before the act of intellectualisation by an author. I do not mean "before" in the sense of the unconscious psyche. I mean the shared environing world or Umwelt through which one filters out meant objects, not a selfsufficient subject whose act is believed to begin when s/he intends an object. When I say that the act of meaning is "before" the act of intellectualisation, I mean "before" as an existence condition of the acts of intellectualisation. The condition may include a shared environing world. Here, collective memories aid in inculcating the preiudicia of the shared meant world.

The immediate object itself is not perceptible nor is it an object of thought. We cannot find a discrete chronological time when the act of meaning originated. Though a singular act, the act itself draws from a complexity of factors making for an act of meaning. Because of the absence of such a temporal origin, it is not surprising that jurists of conceptual jurisprudence have excluded acts of meaning from the identity of law. An act of meaning is not even quotable because it is not the product of reflection or deliberation. Nor is it accessible as an object of psychology. Certainly some forms of psychology, like descriptive sociological jurisprudence, observe the human agent as if an object "out there" in an objectivity separate from the observer-jurist-psychologist. Instead, the agent is a stranger to the law precisely because the acts of meaning of the jurist draw from the jurist's personal and collective memories and expectations. The stranger may well lack such. The challenge is to wonder whether the concept-centred written language can access the acts of meaning of the stranger. The issue is familiar to students of Jacques Derrida. ${ }^{82}$ Unless such an issue can be addressed affirmatively, a phenomenology of human rights will lack the universality, albeit a socially contingent universality, attributed to human rights.

In sum, an act of meaning is unwritten in that it lacks an origin in calendar time and territorial space. As Antigone describes her unwritten laws,

These laws weren't made now or yesterday. They live for all time, and no one knows when they came into the light. ${ }^{83}$

This lack of an origin raises issues concerning the nature of legal obligation?

\subsection{The Meaning-Constituting Acts Exemplified: Sophocles'Antigone}

This sense of an unmediated intuition is not something new to legal thought. Indeed, Sophocles raised the prospect of unmediated intuitions in his Antigone. ${ }^{84}$ Antigone's two brothers had killed themselves in battle. The king considered Polyneices a rebel when he took up arms against Thebes. The king, after calling his council together, stated an edict to the effect that no one should bury Polyneices' body. The king initially imposed that anyone who contravened the edict would be stoned. The king's edict, however, clashed with the unwritten ritual of Antigone's clan to the effect that the eldest of the family had an obligation to bury the body of a family member killed during battle. In response to the latter obligation, Antigone initially spread sand over Polyneices' body in the night and then, in broad daylight on the following day, she laid stones over the body.

On the initial violation of the edict, ${ }^{85}$ Antigone did not reflect or deliberate with

\footnotetext{
${ }^{82}$ See eg. Derrida [1994] 2002, 237-8; Derrida [1997] 2000. See esp. Fitzpatrick 2008. 2001)

${ }^{83}$ Sophocles, Antigone, line 457-58 (trans. with Intro \& notes by Paul Woodruff, Hackett, Indianapolis,

${ }^{84}$ Sophocles, Antigone.

${ }^{85}$ It seems that Antigone had symbolically fulfilled her obligation by spreading sand over the body. When she went out in broad daylight and placed stones over the body, she had arguably "thought through" her
} 
her little sister as to whether she should not follow the custom. ${ }^{86}$ Nor did Antigone even rationally intuit that she ought to be bound to follow the ritual. Without thinking or even debating with her little sister (there was no dialogic space between herself and Ismene), Antigone just went out to the desert late at night and symbolically spread dust over the body. Her expressive acts of burial were gestural, not acts of inscription. Indeed, she did not even consider King Creon's written edict legally binding. When the king confronted Antigone with his edict she rhetorically asked «What law?» For Antigone, a law existed by virtue of her immediacy with a ritual. Antigone experiences such a ritual just as she personally experiences the edict, her prosecution and her sentence. ${ }^{87}$ She experiences the knowledge that her father/half-brother, Oedipus, her half-brother, had committed incest with her mother who, in turn, had begot Antigone and Antigone's siblings. The gods were now wreaking havoc in her conscience. Her little sister had initially refused to support her action against the king, their uncle, or to empathize with her suffering. The early protestations of self-interest by her little sister did not sway Antigone's intuitive decision. The king, her uncle, had issued the very edict which she had disobeyed. The king has sentenced her to be stoned and then he changed the sentence to starvation in a cave. Her two brothers have now killed each other on the battlefield. Her first cousin and fiancé (Haemon) and her mother (the wife of her half-brother/father, Oedipus) committed suicide. Her knowledge was experiential.

Only if the ritual had been "written" in the sense of having been the object of conscious deliberation, only then might we be able to consider the ritual a "custom" according to Hart. She lacked any "critical morality» or "critical reflection», to use Hart's and Dworkin's term, about the ritual. ${ }^{88}$ Her laws were not the object of critical reflection. Antigone did not hesitate nor reflect as to whether there was such a custom or whether the custom should have been applied in the present case. Antigone's "laws" were unwritten and unspoken. They were not codified nor did anyone know when they originated. Her laws lacked signified concepts in that her obligation was represented gesturally, not intellectually by concepts.

Antigone intuited that she ought to obey the ritual. It is not just that Antigone experienced an absence of mediation between herself and the ritual. She had no choice but to obey the ritual. Was Creon's consciously posited edict obligatory for Antigone? First, the written edict contravened the unwritten and unspoken «habit», to use Hart's term, whereby the eldest had a duty to bury the body of a deceased family member. Second, a sentence needed public support. Public stoning required such public support. Third, starvation as a sentence was anathema to the rituals of her traditional society.

Even the "written laws" depended upon experiential knowledge for an obligatory character. An unwritten custom brought an obligatory character to Creon's call of a meeting with the Council. Polyneices had contracted with his brother, Eteocles, that each would share the throne. Although Polyneices was to follow Eteocles as the king of Thebes, Eteocles did not renounce the throne when it was Polyneices' turn. Even such a contract, however, presupposed the pre-intellectual intuition, shared by both brothers, that a promise made ought to be kept. Her uncle, the king, had

${ }^{86} \mathrm{It}$ is likely that the very idea of a "custom" is a concept of European thought, beginning with Plato's Laws. This point is discussed in the context of Inuit "customs" in Oosten and Laugrand 2002.

${ }^{87}$ Hegel discusses this point in Hegel [1821] 1991 [PR], 166R.

${ }^{88}$ Hart 1963, 20; Dworkin 1977, 39-44, 54-5, 59-68.
} 
issued the edict that whoever buried the deceased's body would be stoned to death. ${ }^{89}$ Antigone's experiential knowledge challenged the very obligatory character of the king's proclamation. We are left with the conclusion that two senses of knowledge characterized Sophocles' Antigone: the one was conceptual knowledge and the other was experiential knowledge.

\subsection{The Absence of a Mediating Concept}

The important insight here is that unwritten experienced acts of meaning lack the mediation of concepts. Pre-intellectual experienced events existed before the king's edict took on an obligatory character in the polis. Acts of intellectualisation reduced singularly experienced events - incest by her father/brother and by her mother, her clan's ritual of burying the body of a family member killed in battle, the prospect of being stoned to death and then starved to death, the suicides of her mother and her fiancé, and on it goes - into generalised concepts.

The point, then, is that Antigone's ritual, as a "social convention" (that is, as a regularity of social behaviour in her clan), would begin legal analysis where acts of meaning ended in an intuition. In order to understand an obligation to abide by a habit or even a social convention, one needs to retrieve the condition generating Antigone's intuition that she ought to bury her brother's body. The act of meaning constitutes just such a condition. In this context, one does not begin with ready-made concepts such as "less onerous alternative" or "a compelling state value" - something which could be "prescribed" and "taught" by expert knowers in a professional law school. Nor does one begin with an observable regularity about heterogeneously experienced events. It is naive to believe that the social convention "out there" separate from the jurist and the observed non-expert and indifferent to intuitions experienced in a pre-legal world. It is also naive to say that the jurist perceives experiences as if her/his perception is merely passive and as if the object of perception is a self-generating and self-determining fixed thing. The singularity of an experienced event cannot be categorised in a class or category of "facts". Such a singularity is alien to the universals of a priori concepts.

From the standpoint of legality after the analytic leap from an unwritten (that is, unauthored) to a written (that is, authored) language, the act of meaning is nonanalysable and therefore non-describable. This is so because concepts are authored at a distance moment in calendar time. The act of meaning is external to legal knowledge. Although the legal official may well bring his/her professional or personal experiences into the core of the right/concept (therefore, the penumbra of a concept) or her/his choice of how one concept trumps another, an embodiment of texts and perceptual objects with acts of meaning is excluded from the legal identity of human rights. Only the concept can be included as a unit of the legal structure. The concept possesses a cognitive, not an experiential, character. The attribution of a cognitive denotation takes for granted that there is nothing of relevance before the social facts are generalised as a concept. The decomposition of one concept facilitates the analysis of the next concept. So the substance of the social phenomena - the non-recognisable and non-analysable non-concepts exterior to the boundary of the legal knowledge of concepts - matters nought to the analysis of law.

Acts of meaning have had two features. The one is the constitution of an intuited object such as Antigone's felt obligation to bury her deceased brother's body. The second concerns the fulfilment of such an intuited object. Both experienced moments

\footnotetext{
${ }^{89}$ It is possible that Hart had this story in mind when he raised the scenario of Rex I in HART 2013, 58-61.
} 
are unwritten. Both lack a mediating concept between individual and the intuited object. Such an absence contrasts with the preoccupation with reasons for action in an act of justification.

There is a further feature of acts of meaning. The intuited object is an action. The action is not measurable as if the individual moves from one spot to another. Nor can the action be measured on a clock or weekly calendar. The action is experienced. And the experience moves from an unwritten and unspoken meaning to its fulfilment in an intuition.

The immediacy of a singular experience with an intuited object constitutes a structure. This structure, though, is of intuited objects, not of concepts. The structure, like the intuited objects themselves, is unwritten in the sense that it is not the product of self-conscious thinking. Acts of meaning are in continual flux. Such flux contrasts with the posit of a fixed concept or fact. Intuited objects are immanent or internal to the consciousness of the expert or non-expert as opposed to a consciousness about intellectualizing transcendent concepts external to the expert or non-expert. This immanent character of an act of meaning contrasts with how conceptual jurisprudence has understood an intuition. Conceptual jurisprudence has often referred to intuitions but the intuitions have been described as «rational». ${ }^{90}$ In contrast with rational intuition, an act of meaning is immanent from an individual's consciousness.

\section{Elements of an Act of Meaning}

The point has arrived when one needs to understand what is really forgotten in the analysis of human rights concepts. What exactly is the inaccessible remainder to the human rights standards, rules, doctrines and other guiding concepts in human rights law?

\subsection{The Experiential Body}

The crucial enquiry for the human rights jurist concerns the constitution of a jurist's intuited objects. Unless we study the meaning-acts constituting shared and radically differing intuitions of various peoples and unless we do so as human rights law, strangers will face strangers despite claims to represent the same human rights. Such a meaning of both jurist and stranger is prior to the signifying relation of sign to concept. Such a meaning-constituting act draws from the experiential body. ${ }^{91}$ This body is not the biological body that can be observed, measured, weighed, surgically altered and anatomically studied. Nor is it an object "out there" to be observed as an object of psychology. The experiential body constitutes intuited objects. The objects are intuited, not cognitively constructed. The experiential body fluctuates through experienced time. Time is experienced, not measured, in act of meaning. Nor is an intuited object a product of thinking. There is something that generates the meaning-constituting act internal to the body as an organism..$^{92}$ The inner world of the individual is the Innerwelt. So too, an organism may experience something without that "something" moving or being moved.

What is important to appreciate here, then, is that the intuited objects are lived through one's body, not posited independent of one's body as a priori concepts. Nor are

\footnotetext{
${ }^{90}$ LeITER 2007, 178-9, 183-6.

${ }^{91}$ I draw here from MerLeau-Ponty [1945] 1962, 67-199.

${ }_{92}$ Jacob von Uexküll suggests that protoplasma is just such an internal force. See von UEXKÜLL [1920] 1926, 19, 355. Also see UехкÜLL 1982.
} 
the intuited objects consciously authored as social conventions as if legal knowledge begins with the observation of a convention as a fact. Nor are the meaning-constituting acts justifiable reasons for physical or legal action. Nor does "mindedness" construct the meaning-constituting acts. ${ }^{93}$ When legal analysis begins with a concept, legal knowledge is foreclosed from an examination of intuition-constituting acts. The signs signifying such concepts, however, are hardly transparent once the experiential body is recognized as constituting intuited objects. Various readers will bring diverse experiential meanings into the signs representing the concepts. Such an embodiment of configurations of signs undermines the very possibility of a single uniform core or essence of a concept. What induces the (false) sense of an "essence" or "core" to the signified concept represented by a word is the sharing of intuited objects.

\subsection{Praeiudicia}

The act of meaning, when deeply felt by a natural person, embodies praeiudicia or prejudgments. The reader or listener undergoes an experience as $s /$ he reads the writing or listens to an oral "recounting" of the event. A clarification of a concept or a justificatory argument, in contrast, does not account for a reader's or listener's recognition of the concept or argument about a "social fact". Nor does the clarification of the relation of a word to a concept account for a reader's or listener's recognition of social behaviour. Such a recognition draws from the reader's or listener's acts of meaning experientially and analytically before the law - that is, before the intellectualisation and representation of a social convention as a concept. The act of intellectualization idealises social life as if it can be understood in a heaven of a priori rights/concepts.

The signification of signified concepts as "data" or "social facts" leads the reader or hearer to believe that a conclusion in reasoning about human rights concepts is inevitable or "natural". A sense of "inevitability" or "naturalness" about the justified concepts in search of a core exists, though, at the expense of the praeiudicia. The legal philosopher strives to understand how human rights can be considered units, for example, in a legal objectivity named "the international community as a whole". But if the legal philosopher were ever successful in doing so, the human rights concepts would ironically foreclose philosophy from a study of the intuitions constitutive of legal objectivity. Naivety would colour our reified objectivity of rights/concepts. We would have a philosophy about human rights but not a philosophy of human rights. One may consider the official's role as that of observing and recording the patterns of the behaviour of officials. And yet, because one attempts to comprehend the patterns as the units of legality (such as the patterns of the use of words), human rights laws become a product of speculation.

\subsection{Collective Memories}

The critical point is that human rights, to be universally shared, need a shared sense of belonging to a group, even the group of all people on the globe. That is, intuited objects about human rights need to be constituted from unquestioned assumptions and expectations shared in the group. We need to ask "what generates the shared praeiudicia?" One factor, however, stands out: collective memories. ${ }^{94}$ Collective memories are not personally experienced. Rather, one assimilates the collective memories of her/his group. A family, ethnic group, religious organization or state

\footnotetext{
${ }^{93}$ For a focus on mindedness see Kramer 2007.

${ }^{94}$ See esp.Sturken 1999, 231-48; Nora [1984-1992] 1996-1998, 8, vol 1; Jung 1968
} 
is such a group. The group members may share "memories" as to the origin of the group. The memories may pertain to actual events or myths about the origin of a group. Such collective memories embody the praeiudicia constituting acts of meaning. In particular, one feature of a collective memory is a habit memory. The collective memory may retain the signs and symbols of the group's past out of habit, for example. Conversely, past myths and mystic origins may well be forgotten. ${ }^{95}$ Any such symbol, though, may fade or become stronger through time. ${ }^{96}$ In addition, Maurice Halbwachs (1877-1945) highlighted how social groups «enclose and retrieve remembrances» within a spatial structure. ${ }^{97}$ A territorial sense of space has especially constituted the collective memory of the state-centric legal order of modern times. ${ }^{98}$

\subsection{Meaning-Constitution as an Act}

Unlike the posited social fact, we may now appreciate that the constitution of meaning is an action. As Husserl writes, it is hopeless to look directly at perceived data and to say that "social facts" exist..$^{99}$ One may assert that a burglar has committed murder or that state officials looked the other way while a para-military group massacred thousands of inhabitants. When a lawyer or judge addresses such claims, s/he articulates how the event falls inside the boundary of a ready-made rights/concept. Such a right/concept is erroneously believed to analytically pre-exist the acts of meaning. The right/concept may be justified in terms of a social convention. In this act of intellectualization, the convention, as a concept, is believed to be a fixed social fact. And the law proscribing such an act is conceptualised. The jurist thereby perceives more than a physical act such as a killing. We overlay such a signification with a surplus of meaning drawn from our own memories or forestructures of meaning. Our memories are imagined from the present. ${ }^{100}$ The same holds for the future. The imagination is not some $a$ priori concept in a heaven of concepts but an image drawn from experienced acts of meaning.

Accordingly, a surplus of meaning enclothes a word with a concept, such as a "social convention". ${ }^{101}$ Each subject experiences the event differently because each draws from a different experiential body, praeiudicia, memories and expectations. Contrary to the accepted belief of conceptual jurisprudence in an existence of legal concepts prior to meaning-constituting acts, the seeming priority of concepts is analytically dependent upon the experiential acts. If we remain preoccupied with the right concept of a social convention, we will decompose each possible justified concept into its parts and then revise the parts into a revised concept much as Hart described in the Introduction to his Concept of Law. ${ }^{102}$ We shall aim to clarify the boundary of a concept in this manner. But such a signification of writing excises intuited objects, all the while that we jurists believe that we are accessing justice.

The consequence of this exclusionary character of legal knowledge, then, is that a conceptual human right is institutionalised experientially and analytically after acts of meaning embody the configuration of signs representing the concept of a social convention. The social content of the concept of a human right changes so radically

\footnotetext{
${ }^{95}$ Ricoeur [2000] 2004, 412-56.

${ }^{96}$ Halbwachs [1950] 1980, 82.

${ }^{97}$ Halbwachs [1950] 1980, 157.

${ }^{98}$ I develop this point in ConkLIN 2014, 66-79, 236-40.

${ }^{99}$ Husserl [1900-1901] 2006, 779.

${ }^{100}$ KoseLLECK 2004.

${ }^{101}$ Husserl [1900-1901] 2006, 782.

${ }^{102}$ Hart 2013, 12-6.
}

Metodo. International Studies in Phenomenology and Philosophy

Vol. 2, n. 1 (2014) 
through time that the words signifying concepts may well remain the same despite the varied acts of meaning embodying the content of the concepts. Social actuality shifts and yet, the association of a word with the analytically prior bucket of concepts remains temporally fixed and self-standing. More importantly, the latter association of a word to a concept remains reified from the acts of meaning generating the social character of life.

In sum, a discrete law, as accepted by the dominant tradition of conceptual jurisprudence, is a concept. Legal analysis abstracts from and reduces the acts of meaning to a fixed and a-temporal universal concept. The structure of human rights is a structure of concepts. Indeed, a conceptual human right intellectually encloses the heterology of acts of meaning. Such a conceptual understanding of human rights has been the foreclosure of a social belongingness as material to the very possibility of an identifiable human rights law.

This boundary of legal knowledge is not surprising given the differendbetween a written and unwritten language. We rigorously decompose rights as a priori concepts. We decompose them into the parts of a right/concept as if there were a centre or core of the right/concept. We assume that a right is accessible if the knowers about the right have accessed or, at least, if they have closely reached the centre of the concept as a human right. But such an analysis of a concept/right perpetuates the differend.

Conceptual human rights exemplify just such acts of intellectualisation. Human rights, as argued in my section one, are considered universal because of their contentindependence. Their content is unrecognized because acts of meaning are excluded from legal knowledge. More, legal knowledge is thought to exist by virtue of a justification. The justification, in turn, appeals to a higher-ordered concept such as dignity or humanity or an international community. Human rights become universal because, as Hart describes of a general concept, life is organised in concepts without being «tied to any particular legal system or legal culture.» ${ }^{103}$ Lived meanings are organised and forgotten inside the boundaries of content-independent concepts.

As a consequence, unaccessed acts of meaning remain, the remainder being constituted from meaning-constituting acts experienced by a human rights claimant or, for that matter, by a jurist. Once a concept about a social convention is accepted by the legal elite, ${ }^{104}$ the concept is fixed in time and space, immune from any shift in the assumptions or expectations of the social ethos of the legal community or the wider social communities. The boundary of the social convention as a regularity/concept fixes a heterology of experienced events in time and space. The fixed foundation concept can only «approximate» a social event, Hart points out. ${ }^{105}$ The fixed social event as a concept re-presents regularities (itself a concept) of behaviour, the concept being posited as the starting-point of legal analysis about human rights. Such a starting-point conceals the analytically prior acts of meaning. Hart himself did not deny the existence of acts of meaning. What he did deny was their relevance to the identity of a law. That said, Hart explains at one point that «[v]ery often when a person accepts a rule as binding and as something he and others are not free to change, he may see what it requires... quite intuitively, and do that without first thinking of the rule and what it requires.» ${ }^{106}$ Hart continues that in this prior moment of an intuition before one even speaks or writes, one has «a direct response to the situation.»

${ }^{104}$ And Hart is clear that the «social behaviour» at issue is that of "primarily lawyers, concerned professionally either to teach or practise law, and in some cases to administer it as judges» HART 2013, 2. 
This direct response, he says, is «unmediated by calculation» (such as occurs with a reason for action). A moment later, Hart explains that the recognition of observable regularities of behaviour «cannot reproduce [,] the way in which the rules function as rules in the lives of those who normally are the majority of society.» ${ }^{107}$ At best, as Hart put it, the concept's representation «may very nearly reproduce the way in which the rules (sic concepts) function in the lives of certain members of the group... .${ }^{108}$ And then, the reproduction will be by accident despite the assumption that the social convention, as a concept, grounds human rights law in a social reality. This intuitional relation to an object, admittedly the social reality which can be reproduced by concepts, is excluded from the analysis of conceptual human rights. The conceptual human right is experientially and analytically recognised after the moment of the constitution of an intuited object even though the meaning-constituting act transpires phenomenologically and analytically before the conceptual human right exists.

The conceptual human right is accidental when we consider the social reality of acts of meaning. The accidental representation of an act of meaning is furthered by associating human rights analysis with reasons for action. ${ }^{109}$ By this, one signifies a concept justifying a judge's decision, for example, as if the concept rationally causes a legal action. ${ }^{110}$ A social convention, as the starting-point of human rights legal analysis once again, collapses into a technique or method about decomposing concepts. Although the latter technique highlights «customary legal norms», the norms are only identifiable if recognized as concepts/rules - that is, after the jurist has leapt into acts of intellectualisation about the custom.

\subsection{The Act of Interpretation of Social Behaviour}

Time and space take on a very different character in the act of interpretation. We tend to think that legal time begins with the posit of social conventions. Time in this context is measured by the clock or calendar. Similarly, space is taken as physical or geographic space. Accordingly, a state lays claim to title over the physical space that it controls. Again, space is measureable according to the situs of its border. Space is assumed to be a spot located on a map. This is so because the act of meaning lacks a discrete historical author.

Such a measureable sense of time and space, so commonly accepted by jurists, does not describe the experienced act of meaning. Time and space are experienced by reader or listener, by the parties and victims, and by the lawyers/judge. When one locates a concept/rule about "social conventions" as if measurable in chronological time and territorial space, the interpretation is abstracted from experienced time and space. Time is de-temporalized. This is especially so after the leap from pre-legal acts of meaning into the decomposition of concepts. As a fixed concept, the social conventions are accepted as if no experience transpired before "the facts", as if an historical past discontinuous with the jurist's present. The measurable and abstracted events of the past are retrospectively reconstructed as concepts separate from the jurist's acts of meaning. Intellectualism triumphs over experiential meaning. ${ }^{111}$

With the posit of concepts as the regularity of social behaviour, the concepts begin a legal objectivity, we are led to believe, and yet, the objectivity is reified from the lived

\footnotetext{
${ }^{107}$ HaRt 2013, 90.

${ }^{108}$ Hart 2013, 90. Emphasis added.

${ }^{109}$ This is best elaborated in RAz 1978; WIGgINs 1978.

${ }^{110}$ RAz 1994, 211-5.

${ }^{111}$ CARr 2006.
}

Metodo. International Studies in Phenomenology and Philosophy

Vol. 2, n. 1 (2014) 
acts of meaning of the perpetrator, victim and lawyer/judge. The social conventions, as concepts, abstract from intentional acts of meaning experienced by subjects. The social conventions are self-standing concepts. The jurist generalizes from particular cases about the parties as if the jurist is a stranger to acts of meaning and yet, the jurist does so from the standpoint of the present aggregation of concepts. Such a presence is superimposed upon the remainder to legal knowledge. We must "think like a lawyer", it is often said. The time and space of such subjects is continually changing through time and space.

In sum, the jurist turns inward into a self-consciousness as if s/he can imagine the stranger from the stranger's personal and collective memories. Such may be possible in a dialogic relation. ${ }^{112}$ The horizons of meaning of both jurist and stranger are continually moving. The jurist is presupposed to possess a consciousness even before $\mathrm{s} /$ he begins to become self-conscious about her/his institutional role and then become deliberative about the social-cultural content of rights/concepts. The stranger, in turn, reads her/himself into others so as to constitute intuited objects. The picture of the non-expert knower mirrors the jurist's structure of concepts. There is no closure "in sight" ${ }^{113}$ The jurist thereby determines legal objectivity. The objectivity is meant, not conceptualized.

\section{The Universality of Human Rights}

The importance of acts of meaning poses the question whether human rights are universal. After all, the universality of human rights has been taken as possible by virtue of the content-independence of universal human rights. Some ultimate concept, such as dignity or a social convention, is considered universal because it lacks socially contingent content. An act of meaning, however, is socially contingent. The latter contingency invites the charge of moral relativism rather than of moral universality. I now wish to suggest that a universality does characterize the archaeology of a knowledge about human rights.

V. N. Volośinov (1895-?), alias Mikhail Bakhtin, offers insight as to how one might approach the possibility of a phenomenal universality of human rights. Volośinov, highlighted how a dialogic relation emerges from acts of meaning. ${ }^{114}$ Lev Vygotsky adds that acts of meaning are absorbed during early childhood from the child's personal experiences. ${ }^{115}$ For my part, I project a spectre or picture of the other onto the other. My picture re-presents the other. I embody my picture with my intuited objects. If I only perceive the other as a "social fact" to be observed, I lose any opportunity or possibility that the other has acts of meaning and that the other embodies her/his own utterances and writing with her/his own experiential knowledge. If I recognize the other as embodying utterances with intuited objects, I and the other live through the other's meant objects by participating in a dialogue.

A dialogue, unlike the "social convention", as the emanation of a source, takes on a life of its own with one partner responding to another. Such a response to a response contrasts with a monologue. A monologue leaves little experiential space or time for the addressee to respond. When a natural person or a state official claims to justify a right in terms of a social convention as if we can access social life by reference

\footnotetext{
${ }^{112}$ ConKLin 1998, 213-48.

${ }^{113}$ The best explanation of this, though addressing human experience generally rather than legal experience, is HARRIS 1955, 17-21.

${ }^{114}$ BaKhtin 1986; BaKhtin [1930] 1981; Volosinov [1929] 1973.

${ }^{115}$ Vygotsky [1934] 1962; Vygotsky [1927] 1982, vol. 1.
} 
to a concept, a monologue characterises the relation of the expert knower author and non-knower of the concepts. ${ }^{116}$ Galit Sarfaty has explained how expert knowers of human rights concepts have carried on just such a monologue side by side with non-knowers of the concepts. The knowers he has had in mind are economists - the economists being the expert knowers - in the World Bank. ${ }^{117}$

In a dialogic relation, however, a hearer, drawing from acts of meaning filtered through her/his environing world, intuitively understands the speaker's or author's expression. ${ }^{118}$ Such an intuitive understanding draws from the addressee's and addressor's environing worlds (Umwelten). The dialogic relation may well characterize the discourse of expert knowers of the concepts represented by words and phrases and sentences. And yet, a monologic relation characterizes the relations of expert knowers and non-knowers. ${ }^{119}$ The speaker/author and addressee/reader analogizes or imagines what the one means by the other's writing or utterance. Each is a stranger to the other. It is not race, colour, sex, language, religion, political or other opinion, national or social origin, property, birth or other status which renders one a stranger to the written language of concepts. Such criteria of difference are concepts. One is a stranger to another by virtue of the differing acts of meaning which remain unshared in the addressive experiences of each to the other.

One cannot self-consciously retrieve the intuitions of the other unless one enters into a dialogical relation with the stranger to their own Umwelt. The stranger may be another human being, a parliament's or court's writing or, for that matter, oneself. In such a dialogical relation, a response to a response takes on a life of its own, independent of what we have taken as a regularity of social behaviour. Writing becomes "alive" by virtue of the acts of meaning embodying authored such writing as a statute or treaty or a judges expression of her/his reasons for action. This embodiment of meaning into the other's expression constitutes what jurists have called «a living constitution» or what Montesquieu called «the spirit of the law». To the extent that legality provides openings for diverse experiential meanings in the reading of social conventions as well as texts, the environing worlds of readers embody a spiritual renewal in the conventions and texts, just as Husserl argued. ${ }^{120}$

Georg Hans Gadamer makes a similar point in his Man and Language. ${ }^{121}$ Here, he argues that if one speaks or writes through acts of signified as an object of understanding, then one does not really speak or write. One may write or speak the same vocabulary and grammar and yet, write or speak past the other. One may interpret a text or social event and yet misdirect such an interpretation in a manner that misses a consideration of the constituting act of meant objects of a person believed to be worthy of human right protection. Because of radically different experiences, the act of signification produces a rupture between us. Writing makes sense to the reader when $\mathrm{s} /$ he shares a structure of meant objects inside an horizon or boundary of such objects. When one responds to a text through such a shared horizon of meaning, a consensus may be reached amongst expert knowers of the text. Such a consensus marks a horizon of meaning. Gadamer describes such a horizon as constituted from praeiudicia (or prejudgments). Such a horizon, though, is revisable as the addressive experience is acculturated into one's respective praeiudicia. One lawyer, filtering out writing through

\footnotetext{
116 For a further examination of this see ConkLin 1998, 15-8. See also ConkLin 2011, 145-72, 273-305.

${ }^{117}$ SARFATY 2012.

${ }^{118}$ See ConKLin 1998, 209-40, 243-4.

${ }^{119}$ This claim is elaborated in CoNKLIN 1998, 51-68, 115-8, 214-21.

${ }^{120}$ Husserl [1954] 1970, 390. Also see Husserl [1954] 1970, 275.

${ }^{121}$ GADAMER 1976.
}

Metodo. International Studies in Phenomenology and Philosophy

Vol. 2, n. 1 (2014) 
her/his environing world or Innerwelt inculcated from a professional legal training (as opposed to education), may well respond to a text differently from another lawyer. But when the same words are read by a lawyer and a non-lawyer, an untranslatable gulf may well separate the readings because of the very different environing worlds of the lawyer and non-lawyer. The one may well experience a movement in the assumptions and expectations making for the horizon of meanings. The stranger may well carry my meant objects one step further in a dialogic relationship.

This dialogic relation, however, needs to be clarified in the context of acts of meaning in a legal discourse. Meant objects of an expert knower of the concepts represented by familiar signs in a legal discourse may well be carried one step further in response to the signified relations of another expert knower. The legal discourse, like the medical discourse, is protected by organizations which possess the authority to admit, expel and withdraw the license to claim knowledge about the familiar signs. In such a context, as an expert knower of familiar signs in my professional discourse, may well move my horizon of meanings in response to the signifying relations of another expert knower. In the phenomenal situation of each of us, we may well begin responses with very different Umwelten drawn from our personal professional experiences. We may begin with different assumptions and expectations as to the role of a lawyer or judge, the identity of a law and the nature of legal obligation. Once I respond to the configurations of signs of the other professional knower, my own acts of meaning may well be carried one step further.

When the same configurations of signs are read or heard by a non-expert knower of the signs, it is unclear whether a dialogic relation can ever be achieved. The crucial issue concerns what the expert knower and non-expert understand as the identity of a law or, for that matter, why an agreed sense of meaning as to what is a law is binding. Jacques Derrida, for his part, assumed that a law manifested a written language about content-independent concepts. ${ }^{122}$ With such a view of the identity and nature of a law, one may well question whether a dialogic relation between expert knowers, which share such a Kantian view of law, can ever possess a dialogic relation with non-experts. If the identity(what is the justified source of a rule?) and nature (why are identifiable laws binding?) draw from an understanding of law as identified in terms of social relationships and as binding because of such social relationships as constitutive of the legal bond, then a dialogic relation might well be possible between expert knower and non-expert. ${ }^{123}$ This is so because "what is a law?" hinges upon the very social-cultural content which generates acts of meaning.

Once the latter is retrieved, one can better understand how acts of meaning constitute a human right in context-specific experiences. Absent a consideration of the experiential meanings, the (Kantian) conceptual human rights abstract from one's meant objects. This phenomenon is what William Twining may have meant by «abstract concepts». ${ }^{124}$ Contrary to Ronald Dworkin's claim that a sharing of an intellectually constructed structure of conceptions renders communication possible, communication is only possible by virtue of shared intuitions before human rights as concepts. The shared intuitions render the content of concepts concrete. Once we recognise the importance of intuitions to the possibility of a human right, legal knowledge becomes the study of addressive experiences. Such experiences are analytically prior to the legality of human rights concepts. And yet, such prior

\footnotetext{
${ }^{122}$ Although "space" prevents me from carrying through with such a claim, see generally DeRRIDA [1994] 2002; ConKLin 2012a, 107-11; and ConkLin 2001, 47-54, 310-1.

${ }^{123}$ See generally ConKLin 2006b, 162-87; ConKLIN 2014, 190-219.

${ }^{124}$ Twining 2002, 335-63, 342.
} 
phenomena are excluded from the legal knowledge associated with the justification of rights/concepts vis-à-vis other concepts such as the regularity of social behaviour. In contrast with a human right being nested in a structure of concepts, prejudgements and expectations constitute horizons of meaning which set the boundaries of meant objects. The jurist or philosopher does not understand a discrete right, itself a concept, if s/he attempts to know the concept by analytically decomposing it into its parts and exceptions. The jurist understands social conventions as social only if $\mathrm{s} / \mathrm{he}$ understands the meaning-constituting acts generating what have heretofore assumed to be social conventions. S/he retrieves the experienced acts of meaning of the stranger. The jurist also understands the writing/speech of the other when s/he recognises the horizons of meaning of the other. It may well be that this explains why Hart associated the social behaviour with "primarily lawyers, concerned professionally either to teach or practise law, and in some cases to administer it as judges,» «most educated people», «any educated man», and «officials». ${ }^{125}$ It is not that legality needs to be turned upside down or that pre-legality be the centre of attention of the philosopher or jurist. Rather, it is that the legal world includes the remainder as well as the concept of "pre-legality". There is no pre-legality external and prior to legality. We cannot put to the side the insights of phenomenology because human rights have only been understood as concepts.

Legal knowledge is now reconciled with phenomenology. Legality only lies in the meant objects of appearances, not in an objectivity of concepts. The latter objectivity has been taken as composed of a-temporal, fixed, and ready-made content-independent concepts. In place of concepts as well as the analytic technique of decomposing concepts, the jurist, sensitive to human rights, is really studying how individuals recognize each other in discursively contingent, context-specific events. Space and time are neither fixed nor quantifiable. Before the jurist presupposes that centralized institutions or social facts legitimize concepts as reasons for action, the jurist must work her or his way through the continual flux of heterology of meanings.

A focus upon acts of intellectualization, represented by a social convention, is misdirected. The pre-intellectual acts of meaning are indeed open to legal study. That all laws (sic concepts) are legally valid if justified in terms of some foundational text, called "the Constitution" or some social convention, posited as a regularity of social behaviour, attracts legal examination in the wrong direction. Legal philosophy always comes on the scene too late to map a blueprint for human rights in advance. Instead, the meaning-constituting acts of the subject, not a structure of concepts, generate legal objectivity. The legal objectivity is intuited, not posited in concepts.

The analytic leap from unwritten acts of meaning to the authored acts of intellectualisation is the product of a subject's consciousness, whether the subject is a lawyer/judge/ legal pedagogue/law student or a disputant. "Social conventions" are not "out there" to be observed separate and independent of the observer. Nor is a community the product of the justifications of a priori concepts. A community exists by virtue of intuited objects whose boundary is experienced through shared horizons of meaning. Instead of gazing outward towards "social facts" or towards concepts from the vantage point of the present (that is, after the leap), the jurist turns inward into her or his own personal and collective memories and inward towards her/his consciousness of the stranger's unwritten language. Unlike a discrete, self-standing concept, a concept of recognition or a narrative of concepts, horizons of meaning are continually moving through the experience of time and space. ${ }^{126}$ The social function

\footnotetext{
${ }^{125}$ See eg. НARt 2013, 2,3.

${ }^{126}$ ConkLin 2006a. This is elaborated and exemplified in the contemporary international law discourse in
} 
of a jurist is to recognise such movement. The movement is recognised by retracing the shared acts of meaning generating the conditions of social conventions.

The Greeks had a term for such shared meant objects: namely, an ethos. An ethos exists temporally and spatially even before the institutional author, such as a legislature or court or state itself, begins to self-consciously will rights as signified concepts. The ethos is accessible by turning inward into the shared Umwelten which one shares with others. ${ }^{127}$ One actually reads her/his own intuited objects into the writing of the stranger before one writes about such a reading. The stranger reads her/his own intuited objects into the writing of the author before the stranger writes down her/his thoughts. No closure of interpretation is in sight until the acts of meaning are fulfilled in an intuition. ${ }^{128}$ The jurist, without addressing the acts of meaning and the shared such Umwelten in a community, embodies the content of the discrete human rights concepts.

In sum, the dominant strain of human rights discourse, associated with the AngloAmerican theory of conceptual jurisprudence, consistently avoids addressing the pre-legality at a cost. The cost is the very possibility of universal human rights, a possibility which is nested in shared acts of meaning in an ethos. When human rights are understood as concepts, the concepts are super-imposed over social-cultural addressive experiences making for intuitions. The consequence is that a silence permeates conceptual human rights. The silence conceals shared acts of meaning constituting a social community. Without such a community, one is hard-pressed to recognise a universality of human rights.

The social actuality of acts of meaning require an examination of the very prelegality excluded from legal analysis in conceptual jurisprudence. The latter avoids and excludes acts of meaning from consideration despite the human rights rhetoric claiming universality to the rights by virtue of the social emptiness of the rights. The universality of human rights exists by virtue of the environing world shared by members of a community. Such a universality is missed in the never-ending appeal to concepts in the one case and the posit of social conventions as regularities of social behaviour in the other. The universality of human rights remains ironically silent despite the claim by so many jurists that a social convention constitutes social reality.

\section{References}

BakHTin, M. [1930] 1981, The Dialogic Imagination: Four Essays, ed. by M. Holquist, trans. by C. EMERson and M. Holquist, University of Texas Press, Austin-London.

- 1986, "The Problem of Speech Genres", in Speech Genres and other Late Essays, trans. by V. McGee, University of Texas Press, Austin.

Bentham, J. [1782] 1970, Of Laws in General, ed. by H. Hart, Athlone Press, London.

- [1789] 1970, An Introduction to the Principles of Morals and Legislation, ed. by J. Burns and H. HarT, Athlone Press, London.

Conklin 2014, esp. 177-219.

${ }^{127}$ See esp. W. MArx 1992, 69-85.

${ }^{128}$ The best explanation of this, though addressing human experience generally rather than legal experience, is HARRIs 1955, esp. pp. 17-21. 
CARr, D. 2006, "Response to Casey, Crowell and Kearney", in Human Studies, 29, pp. $491-501$.

Coleman, J. 2003, The Practice of Principle. In Defence of a Pragmatist Approach to Legal Theory, Oxford University Press, Oxford.

Conklin, W. 1998, The Phenomenology of a Modern Legal Discourse, Darthmouth, Aldershot.

- 2001, The Invisible Origins of Legal Positivism: a Re-Reading of a Tradition, Kluwer, Dordrecht.

- 2006a, "A Phenomenological Theory of the Human Rights of the Alien", in Ethical Perspectives, 13, pp. 245-301.

- 2006b, Hegel's Laws: The Legitimacy of a Modern Legal Order, Stanford University Press, Stanford.

- 2007, "Statelessness and Bernhard Waldenfels' Phenomenology of the Alien", in British Journal of Phenomenology, 38, pp. 280-96.

- 2011, Le savoir oublié de l'expérience des lois, trad. par B. Kingstone, Les Presses de l'Université, Laval.

- 2012a, "Derrida's Territorial Knowledge of Justice", in Reading Modern Law: Critical Methodologies and Sovereign Formations, ed. by R. Buchanan, S. Motha, and S. Pahuja, Routledge, Abington-New York.

- 2012b, "The Exclusionary Character of the Early Modern International Community", in Nordic Journal of International Law, 81, pp. 133-73.

- 2012c, "The Peremptory Norms of the International Community", in European Journal of International Law, 23, pp. 837-61.

- 2014, Statelessness: The Enigma of an International Community, Hart, Oxford.

Cranor, C. 1975, "Toward a Theory of Respect for Persons", in American Philosophical Quarterly, 12-4, pp. 309-19.

CRAwFord, J. 2002, "Introduction", in The International Law Commission's Articles on State Responsibility: Introduction, Text, and Commentaries, Cambridge University Press, Cambridge, pp. 1-60.

Darwell, S. 1977, "Two Kinds of Respect", in Ethics, 88-1, pp. 36-49.

Derrida, J. [1994] 2002, "Force of Law: the Mystical Foundation of Authority", in Acts of Religion, ed. by G. Anidjar, Routledge, New York-London.

- [1997] 2000, Of Hospitality: Anne Dufourmantelle Invites Jacques Derrida to Respond, trans. by R. BowLBY, Stanford University Press, Stanford.

Dickson, J. 2004, "Methodology in Jurisprudence: a Critical Survey", in Legal Theory, 10-3, pp. 117-56.

Duвois, D. 2009, "The Authority of Peremptory Norms in International Law: State Consent or Natural Law", in Nordic Journal of International Law, 78-2, pp. 133-75.

Dworkin, R. 1977, Taking Rights Seriously, Harvard University Press, Cambridge, MA.

- 1981a, "What is Equality? Part 1: Equality of Resources", in Philosophy \& Public Affairs, 10-4, pp. 283-345.

- 1981b, "What is Equality? Part 1: Equality of Welfare", in Philosophy \& Public Affairs, 10-3, pp. 185-246.

- 1986, Law's Empire, Harvard University Press, Cambridge, MA.

- 2002, "Thirty Years On", in Harvard Law Review, 115, pp. 1655-87.

— 2003, "Equality, Luck and Hierarchy", in Philosophy \& Public Affairs, 31-2, pp. 190-8.

- 2013, Justice for Hedgehogs, Harvard University Press, Cambridge, MA.

Endicotr, T. 2004, "Law and Language", in Oxford Handbook of Jurisprudence and legal Philosophy, ed. by J. Coleman, S. Shapiro, and K. Himma, Oxford University Press, Oxford. 
Finnis, J. 2009, "Hart as a Twentieth-Century Political Philosopher", in American Journal of Jurisprudence, 54, pp. 163-71.

- 2011, Philosophy of Law, Oxford University Press, Oxford-New York.

FitzPatrick, P. 2003, "“Gods would be needed": American Empire and the Rule of (International) Law", in Leiden Journal of International Law, 16, pp. 429-66.

- 2005, "Justice as Access", in Windsor Yearbook of Access to Justice, 23, pp. 3-16.

- 2008, Law as Resistance: Modernism, Imperialism, Legalism, Ashgate, Burlington.

Gadamer, H. 1976, "Man and Language", in Philosophical Ermeneutics, ed. by D. Linge, University of California Press, Berkeley, pp. 59-68.

Halbwachs, M. [1950] 1980, The Collective Memory, ed. by M. Douglas, trans. by F. Ditter and V. Ditter, Harper \& Row, New York.

Harris, H. 1955, Hegel: Phenomenology and System, Hackett, Indianapolis.

HART, H. 1952, "Signs and Words", in Philosophical Quarterly, 70, pp. 59-62.

- 1954, "Definition and Theory in Jurisprudence: An Inaugural Lecture (delivered before the University of Oxford on 30 May 1953)", in Law Quarterly Review, 70, pp. 21-48.

- 1958, "Positivism and the Separation of Law and Moral", in Harvard Law Review, 71-4, pp. 593-629.

- 1963, Law, Liberty, and Morality, Stanford University Press, Stanford.

- 1977, "American Jurisprudence Through English Eyes: the Nightmare and the Noble Dream", in Georgia Law Review, 11, pp. 969-989.

- 1982, "Legal Duty and Obligation", in Essays on Bentham, Clarendon, Oxford.

- 1983, Essays in Jurisprudence and Philosophy, Clarendon, Oxford.

- 2013, The Concept of Law, 3rd ed. Clarendon, Oxford.

Hegel, G. [1821] 1991, Elements of the Philosophy of Right, ed. by A. Wood, trans. by H. Nisbet, Cambridge University Press, Austin-London.

- [1835] 1975, Philosophy of Fine Art, trans. by O. F.B.P., Hacker, New York.

Himma, K. (ed.) 2011, The Nature of Law: Philosophical Issues in Conceptual Jurisprudence and Legal Theory, Foundation Press, New York.

Husserl, E. [1900-1901] 2006, Logical Investigation, trans. by F. J.N., Routledge, London.

- [1954] 1970, Crisis of the European Sciences, trans. by D. CARR, Northwestern University Press, London.

Jackson, F. 1998, From Metaphysics to Ethics: A Defense of Conceptual Analysis, Oxford University Press, Oxford.

Joseph, H. 1948, Knowledge and the Good in Plato's Republic, ed. by H. Hart, Oxford University Press, London.

Jung, C. 1968, "The Concept of the Collective Unconscious", in Literature in Critical Perspective, ed. by W. Gordon, Appleton-Crofts, New York.

Kant, I. [1797] 1996, Metaphysics of Morals, ed. by R. Sullivan, trans. by G. M., Cambridge University Press, Cambridge.

- [1797] 1999, Metaphysical Elements of Justice, trans. by J. LADD, Hackett, Indianapolis.

Koselleck, R. 2002, The Practice of Conceptual History: Timing History, Spacing Concepts, trans. by T. Presner, Stanford University Press, Stanford.

- 2004, Future Past: On the Semantics of Historical Time, trans. by K. TRIBE, Columbia University Press, New York.

Kramer, M. 2000, "How Moral Principles Can Enter the Law", in Legal Theory, 6-1, pp. 83-108.

- 2002, "Throwing Light on the Role of Moral Principles in the Law: Further Reflections", in Legal Theory, 8-1, pp. 115-43. 
Kramer, M. 2004, "On the Separability of Law and Morality", in Canadian Journal of Law \& Jurisprudence, 17-2, pp. 315-35.

- 2007, Objectivity and the Rule of Law, Cambridge University Press, Cambridge.

- 2011, "For the Record: A Final Reply to N.E. Simmonds", in American Journal of Jurisprudence, 56-1, pp. 115-33.

Leiter, B. 2001, "The Naturalistic Turn in Legal Philosophy", in American Philosophical Association Newsletter on Philosophy and Law, Spring, pp. 142-6.

- 2003, "Beyond the Hart/Dworkin Debate", in American Journal of Jurisprudence, 48, pp. 17-51.

- 2007, Naturalizing Jurisprudence: Essays on American Legal Realism and Naturalism in Legal Philosophy, Oxford University Press, Oxford.

- 2011, "Naturalized Jurisprudence and American Legal Realism Revisited", in Law and Philosophy, 30-4, pp. 499-516.

MacCormick 2008, H.L.A. Hart 2nd ed. Stanford University Press, Stanford.

Marx, K. [1843] 1978, "On the Jewish Question", in The Marx-Engels Reader 2nd ed. Ed. by R. TuCKER, Norton, New York-London.

Marx, W. 1992, Towards a Phenomenological Ethics: Ethos and the Life-World, State University of New York, Albany.

Merleau-Ponty, M. [1945] 1962, Phenomenology of Perception, trans. by C. SMith, Routledge \& Kegan Paul, London.

- [1960] 1964, "The Philosopher and Sociology", in Signs, trans. by R. McClearY, Northwestern University Press, Evanston.

Mill, J. [1859] 1962, "On Liberty", in Utilitarianism, ed. by M. Warnock, William Collins, Glasgow.

NorA, P. (ed.) [1984-1992] 1996-1998, Realms of Memory: Rethinking the French Past, trans. by A. Goldhammer, Columbia University Press, New York.

Oosten, J. and F. LaUgrand 2002, "Quajimajatuqangit and Social problems in Modern Inuit Society: An Elders Workshop on Angakkuuniq", in Études/Inuit/Studies, 26, pp. 17-44.

Perry, S. 1998, "Hart's Methodological Positivism", in Legal Theory, 4, pp. 427-67.

- 2001, "Hart's Methodological Positivism", in Hart's Postscript Essays on the Postscript to 'The Concept of Law', ed. by J. Coleman, Oxford University Press, Oxford.

Raz, J. 1978, "Reasons for Action, Decisions and Norms", in Practical Reasoning, ed. by J. Raz, Oxford University Press, Oxford.

- 1994, Ethics in the Public Domain: Essays in the Morality of Law and Politics, Clarendon, Oxford.

- 2001, "The Nature of the Theory of Law", in Hart's Postscript Essays on the Postscript to 'The Concept of Law', ed. by J. Coleman, Oxford University Press, Oxford.

Ricoeur, P. [2000] 2004, Memory, History, Forgetting, trans. by D. Blamey K. Pellauer, University of Chicago Press, Chicago.

Sarfaty, G. 2012, Values in Translation: Human Rights and the Culture of the World Bank, Stanford University Press, Stanford.

Schlütter, B. 2010, Developments in Customary Law, Brill, The Hague.

Schutz, A. [1953-1954] 1967, Collected Papers: l. The Problem of Social Reality, Nijhoff, The Hague.

Simmonds, N. 2007, Law as a Moral Idea, Oxford University Press, Oxford.

- 2011, "Kramer's High Noon", in American Journal of Jurisprudence, 56-1, pp. 135-50.

SopHocles 2001, Antigone, ed. by P. Woodruff, Hackett, Indianapolis.

Metodo. International Studies in Phenomenology and Philosophy

Vol. 2, n. 1 (2014) 
Sturken, M. 1999, "Narratives of Recovery: Repressed Memory as Cultural Memory", in Acts of Memory: Cultural Recall in the Present, ed. by M. BAL, J. CRewE, and L. SpItzer, University Press of New England, Hanover-London.

Twining, W. 2002, The Great Juristic Bazaar, Ashgate, Dartmouth, Aldershot.

Uexкüll, J. v. [1920] 1926, Theoretical Biology, trans. by D. Mackinnon, Kegan Paul, London.

- 1982, "The Theory of Meaning", in Semiotics, 92, pp. 25-82.

Vlastos, G. 1962, "Justice and Equality", in Social Justice, ed. by R. BRAndT, PrenticeHall, New Jersey.

Volosinov, V. [1929] 1973, Marxism and the Philosophy of Language, trans. by L. MATEJKA and I. Titunik, Seminar Press, New York.

Vygotsky, L. [1927] 1982, The Historical Meaning of the Crisis in Psychology, trans. by S. SochineniI, Pedagogika, Moscow.

- [1934] 1962, Tought and Language, trans. by E. Haufmann and G. VAKER, MIT Press, Boston.

Waldron, J. 1999, The Dignity of Legislation, Cambridge University Press, Cambridge. Weissbrodt. 2008, The Human Rights of Non-Citizens, Oxford University Press, Oxford. Wiggins, D. 1978, "Deliberation and Practical Reason", in Practical Reasoning, ed. by J. RAz, Oxford University Press, Oxford.

Williams, B. 1972, "The Idea of Equality", in Philosophy, Politics and Society, ed. by P. Laslett and W. Runciman, Oxford University Press, Oxford. 